\title{
ESTABLISHMENT OF A MULTI-PARTICLE EROSION MODEL BASED ON THE LOW-CYCLE FATIGUE LAW - AN EXPERIMENTAL STUDY OF EROSION CHARACTERISTICS
}

\author{
UVEDBA MODELA EROZIJE, NA OSNOVI ZAKONA ZA \\ MALOCIKLIČNO UTRUJANJE, ZARADI UDARJANJA MNOŽICE \\ DELCEV NA JEKLENE STENE - EKSPERIMENTALNA ŠTUDIJA \\ ZNAČILNOSTI EROZIJSKE OBRABE
}

\author{
Mingfei $\mathrm{Li}^{1}$, Yihua $\mathrm{Dou}^{1}$, Hong $\mathrm{Li}^{2}$, Jiarui Cheng ${ }^{*}$, Wenlan Wei ${ }^{1}$ \\ ${ }^{1}$ School of Mechanical Engineering, Xi' an Shiyou University, Xi' an City, 710065, China \\ ${ }^{2}$ PetroChina Xinjiang Oilfield Company, Karamay City, 834000, China
}

Prejem rokopisa - received: 2019-06-06; sprejem za objavo - accepted for publication: 2020-02-12

doi:10.17222/mit.2019.120

\begin{abstract}
In order to obtain a multi-particle erosion model for the prediction of the erosion law of plastic metal walls considering material hardening, the low-cycle fatigue theory and a single-particle erosion model are theoretically combined. In addition, a gas-solid jet experiment wherein the number of particle impacts can be controlled is performed to identify the variation in the material hardness and erosion rate with particle impact times. The experiment tests the change of surface hardness and material loss rate, and obtains the key coefficients in the model and critical impact times of material loss by varying the particle impact number and the impact velocity. Results show that the local yield strength of the material surface will increase because of the hardening effect exerted by the particle impact. Surface hardening results in a logarithmic reduction in the erosion rate with an increase in particle impact number. In addition, there is a critical particle time, which corresponds to material loss and nonlinearly decreases with the increase in the impact velocity, that leads to material loss.

Keywords: multi-particle erosion, hardening discipline, critical impact times, low-cycle fatigue
\end{abstract}

Avtorji tega članka opisujejo študijo s katero so želeli izdelati model erozije zaradi udarjanja velikega števila delcev v plastično kovinsko steno $\mathrm{z}$ upoštevanjem teorije utrjevanja materiala, teorije malocikličnega utrujanja in erozijskega modela enega delca. Izvedli so erozijski preizkus v katerem so številni delci v curku plina kontrolirano udarjali v steno materiala. Analizirali so spremembe trdote materiala in hitrost erozijske obrabe glede na čase udarjanja. S preizkusom so spremenili trdoto površine materiala in hitrost erozije (izgubo na masi). S spreminjanjem števila udarcev delcev in udarne hitrosti so dobili ključne koeficiente modela in kritične udarne čase glede na izgubo materiala. Rezultati so pokazali, da lokalna meja plastičnosti površine materiala narašča zaradi učinka utrjevanja $v$ odvisnosti od števila udarcev delcev. Utrjevanje površine materiala in logaritmično zmanjšanje hitrosti erozije narašča z naraščanjem števila udarcev delcev. Avtorji so ugotovili, da obstaja kritični čas delca, ki se ujema z izgubo materiala in se nelinearno zmanjšuje z naraščanjem hitrosti udarcev, kar vodi do izgube (erozije) materiala.

Ključne besede: erozija z udarjanjem velikega števila delcev, zakoni utrjevanja, kritični udarni časi, malo ciklično utrujanje

\section{INTRODUCTION}

The constant impact of particles in a multiphase flow on walls may cause the deformation or mass loss of wall material. This phenomenon is commonly referred to as particle erosion. Severe particle erosion causes major problems, such as wall-thickness reduction, structural fracture, and equipment failure, and other issues that affect production safety. Particle erosion may involve a single (cutting failure) or multiple steps (fatigue failure). ${ }^{1-3}$ Multistep particle erosion comprises extrusion, stretching, fracture, and shedding processes. This process could only be analyzed by simplifying the fatigue abrasion behavior of plastic metal under repeated impact load given its complexity. 4,5

*Corresponding author's e-mail: cjr88112@163.com (Jiarui Cheng)
Researchers have proposed more than 30 scouring models for the prediction of particle erosion in plastic and brittle materials, since Finnie ${ }^{6}$ first systematically proposed the theory of plastic material erosion in 1958. Tilly ${ }^{7}$ divided the scouring process into two steps on the basis of experimental measurements. First, the impact of particles on the material surface causes the material to press towards the periphery. Then, the material is squeezed again and peeled off through subsequent particle impacts. Studies on multi-particle erosion can refer to fatigue failure research given that the mass loss of plastic materials is usually the result of multiple particle impacts.

The fatigue life of plastic materials is usually divided into short- and long-lifetime zones. Plastic strain plays a major role in the long-lifetime zone. The material failure loading cycle in the long-lifetime zone is short and belongs to the high-load and low-cycle fatigue category. 
Elastic strain plays a leading role in the short-lifetime zone. The small initial contact area between particles and the wall results in remarkably high contact stress. Therefore, multi-particle erosion is generally classified in the low-cycle fatigue research category. Guo ${ }^{8}$ performed a round head impact test to measure the erosion rate of materials. Their experimental results showed that the minimum particle impact numbers that cause material loss at impact velocities of $2 \mathrm{~m} \cdot \mathrm{s}^{-1}$ and $15 \mathrm{~m} \cdot \mathrm{s}^{-1}$ are 1,585- and 4-fold, respectively. This result shows that the material-loss process approaches cutting failure when the particle impact velocity is high. Hutchings ${ }^{9}$ used the low-cycle fatigue theory to establish an erosion model on the basis of dynamic hardness and ductility and obtained the velocity index of circular particles perpendicular to the wall. Huang ${ }^{10}$ also established a multi-particle erosion-prediction model on the basis of the low-cycle fatigue theory. This model includes numerous considerations and a heavy experimental workload as it contains multiple physical quantities and empirical parameters.

We have also established a material deformation model for calculating a single particle impact, ${ }^{11}$ which can successfully calculate the elastic-plastic deformation of the material, the contact time between the particles and the wall, and the size of the impact crater. However, as most scholars have found, particle impact erosion is an ongoing process. The whole process involves material fatigue, fracture and material hardening, which requires the establishment of a multi-particle impact erosion model that considers these factors. Therefore, in this work, we constructed a multi-particle erosion model that considers the fatigue on the basis of our established single-particle erosion model. We performed a gas-solid jet flow experiment to identify the key parameters of the model and identify the relationship between the erosion rate and the particle impact times. Finally, we obtained a linear section of the erosion rate and critical impact times corresponding to the material loss.

\section{FATIGUE DAMAGE ANALYSIS}

As reported in our previous study on single-particle impact erosion, the volume of the eroded crater is as follows:

No sliding contact: $V_{\mathrm{s}}=\frac{1}{3}\left(L_{\mathrm{s}} r_{\mathrm{p}}^{1 / 2} h_{\mathrm{s}}^{3 / 2}+r_{\mathrm{p}} h_{\mathrm{S}}^{2}\right)$

Sliding contact: $\quad V_{\mathrm{s}}=\frac{1}{3} L_{\mathrm{S}} r_{\mathrm{p}}^{1 / 2} h_{\mathrm{S}}^{3 / 2}$

where $h_{\mathrm{S}}$ and $L_{\mathrm{S}}$ are the indentation depth and length of an erosion crater, respectively; $r_{\mathrm{p}}$ is particle radius.

As shown in Figure 1a, the traditional tension-compression fatigue loading is tensile force-pressure alternate change. Metal surfaces usually experience low-stress and long-life-strain fatigue damage when the maximum loading is less than the materials' yield limit.
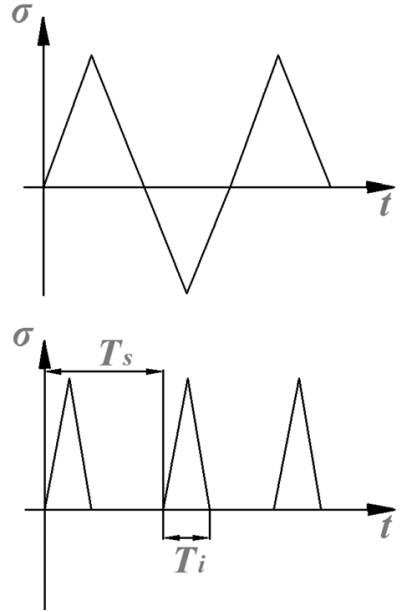

Figure 1: Schematic of load changes during different cyclic loading processes

However, when the maximum loading exceeds the yield limit, metal surfaces will experience high-stress and short-life strain fatigue damage. During multiple impact fatigue processes, the load continuously acts upon the surface in a discontinuous loading form, as shown in Figure 1b, where Ti is the single loading cycle, and $T_{\mathrm{s}}$ is the loading-time interval.

(a) Tensile and compression tests

(b) Multiple impact test

Hutchings ${ }^{9}$ reported that continuous particle impact erosion can be regarded as a low-cycle fatigue fracture process. The fatigue life of material loss can be expressed as a power function of the plastic strain scope $\Delta \varepsilon$ in accordance with the Coffin-Manson formula.

$$
\varepsilon=2 \Delta \varepsilon \cdot N^{\mathrm{b}}
$$

where $b$ indicates the material's characteristic parameters, which are given by Coffin and Manson as -0.5 and -0.6 , respectively. Given that the fatigue energy analysis by Martin provided $\mathrm{b}=-0.5$, the $b$ value is set as -0.5 in this work. The total indentation depth when the particle impacts the same wall surface $\mathrm{N}$ times can be expressed as follows:

$$
h=D h_{\mathrm{S}}\left(\frac{\Delta \varepsilon}{2 \varepsilon}\right)^{-2}
$$

No material loss can be observed in the region of a smooth and flat metal surface under multiple particle impacts when the particle impact time is within the interval $0-N$. However, cracks initiate and develop on the surface. The surface material falls off when the particle impact time is greater than $N$, and the lower layer material undergoes continuous compressional deformation to initiate alternate peeling. The weight loss due to multiple particle erosions will stabilize after a certain time if the material hardening is neglected.

The tangential velocity component for the surface under multiple particle impacts is small. Thus, weight loss due to erosion fatigue is expressed as follows: 
$\begin{array}{ll}V_{s}=0 & N_{\mathrm{c}}<N \\ V_{s}=\frac{1}{3}\left(L_{\mathrm{s}} r_{\mathrm{p}}^{1 / 2} h_{\mathrm{S}}^{3 / 2}+r_{\mathrm{p}} h_{\mathrm{S}}^{2}\right) & N_{\mathrm{c}} \geq N\end{array}$

$\mathrm{Guo}^{8}$ obtained the relational expression between $\mathrm{N}$ and $h$ by taking the logarithm. In contrast to the cyclic loading mode, the metal surface will experience hardening during multiple particle impact processes. Hardening increases the yield limit of the local material to reduce the erosion rate. Stress presents a nonlinear relation with strain during plastic strain. The following expression can be obtained in accordance with the Zener-Hollom formula:

$$
\sigma=k_{\mathrm{s}} \cdot \varepsilon^{n_{2}}
$$

Meanwhile, the following equation can be obtained by taking the logarithm of the two sides:

$$
\lg \sigma=\lg k_{\mathrm{s}}+n_{2} \lg \varepsilon
$$

The hardening index can be expressed in accordance with the relationship between the hardening index and the material strength inferred by $\mathrm{Hu}{ }^{12}$

$$
n_{2}=0.34\left(1-\sigma_{\mathrm{s}}^{\prime} / \sigma_{\mathrm{b}}^{\prime}\right)-0.05
$$

where $\sigma_{\mathrm{s}}{ }^{\prime}$ and $\sigma_{\mathrm{b}}{ }^{\prime}$ are material yield strength and tensile strength under cyclic loading, respectively. Equation (8) implies that the deformation hardening index is a nonconstant value that will change with particle impact times and finally reach a stable value. ${ }^{13}$ As a general rule, $\sigma_{\mathrm{s}}{ }^{\prime}$ and $\sigma_{\mathrm{b}}{ }^{\prime}$ under impact times can be measured experimentally to solve the indentation depth $h$ at a specific time. However, in actual operation, a single measurement of yield strength or tensile strength of the metal surface is difficult to obtain. Hence, a multiimpact experiment is generally subject to the measurement of changes in surface hardness. Many scholars ${ }^{14}$ have obtained a linear relation between the yield strength and the hardness through the numerical regression of the experimental results.

$$
\sigma_{y}=a H V+b
$$

Hence, the yield limit at a specific time can be solved by measuring the value when the measured hardness is stable. Then, the yield limit can be substituted into Equation (9) to replace the vertical material yield limit $\sigma_{\mathrm{y}}$. Subsequently, $\sigma_{\mathrm{y}}$ is substituted into Equation (4) to solve the material loss. If the erosion rate on the wall surface is evaluated by using material loss within a unit area and time, the erosion rate under a tangential non-slipping particle impact can be expressed as follows:

$$
\begin{array}{ll}
C_{\mathrm{E}}=0 & N_{\mathrm{c}}<N \\
C_{\mathrm{E}}=\frac{1}{3}\left(L r_{\mathrm{p}}^{1 / 2}\left(2 h N_{\mathrm{c}}^{\mathrm{b}}\right)^{3 / 2}+r_{\mathrm{p}}\left(2 h N_{\mathrm{c}}^{\mathrm{b}}\right)^{2}\right) & N_{\mathrm{c}} \geq N^{\prime}
\end{array}
$$

where $N_{\mathrm{c}}=\frac{3 r^{2} u^{\mathrm{a}} Q_{\mathrm{v}}}{4 r_{\mathrm{p}}^{3}}, h=\frac{-B+\sqrt{B^{2}-2 A C_{1}}}{2 A}$,

$L=\frac{-B+\sqrt{B^{2}-4 A C_{2}}}{2 A}, A=\frac{1}{2} \sigma_{y} \pi r_{\mathrm{p}}, B=0.17 \times \frac{\pi^{3} \sigma_{y}^{3} r_{p}^{2}}{\left(E^{*}\right)^{2}}$,

$C_{1}=-m_{\mathrm{p}} v_{y 0}^{2}$ and $C_{2}=-m_{\mathrm{p}} v_{x 0}^{2}$

The erosion rate of pipe flow under a tangential slipping particle impact can be expressed as follows:

$\begin{array}{ll}C_{\mathrm{E}}=0 & N_{\mathrm{c}}<N \\ C_{\mathrm{E}}=\frac{1}{3} L r_{\mathrm{p}}^{1 / 2}\left(2 h N_{\mathrm{c}}^{\mathrm{b}}\right)^{3 / 2} & N_{\mathrm{c}} \geq N^{\prime}\end{array}$

where $N_{\mathrm{c}}=\frac{3 r^{2} u^{\mathrm{a}} Q_{\mathrm{v}}}{4 r_{\mathrm{p}}^{3}}, h=\frac{-B+\sqrt{B^{2}-2 A C}}{2 A}$,

$F_{y}=\sigma_{y} \pi r_{\mathrm{p}} h, F_{x}=\frac{v_{x 0}\left(1-\lambda_{x}\right)}{2 v_{y 0}\left(1-\lambda_{y}\right) \sigma_{y} \pi r_{\mathrm{p}} h^{2}}$,

$L=2 \sqrt{r_{\mathrm{p}} h}\left(1-\frac{F_{x}}{\mu F_{y}}\right)^{1 / 3}, A=\frac{1}{2} \sigma_{y} \pi r_{\mathrm{p}}, B=0.17 \times \frac{\pi^{3} \sigma_{y}^{3} r_{p}^{2}}{\left(E^{*}\right)^{2}}$

and $C=-m_{\mathrm{p}} v_{y 0}^{2}$

\section{EXPERIMENTAL PART}

Figure 2a shows the multiphase flow experimental loop, which includes the screw pump, liquid flowmeter, test chamber, sample holder, stirred tank in the liquid flow system and air compressor, buffer tank, filter drier, gas flowmeter, sand storage tank, and PLC feeder in the gas flow system. Particles were added in the gas-solid

Table 1: Chemical compositions of $\mathrm{P} 110$ and $13 \mathrm{Cr}$

\begin{tabular}{|c|c|c|c|c|c|c|c|c|c|}
\hline Material & $\mathrm{C}$ & $\mathrm{Si}$ & $\mathrm{Mn}$ & $\mathrm{Cr}$ & $\mathrm{P}$ & $\mathrm{S}$ & $\mathrm{Ni}$ & $\mathrm{Mo}$ & $\mathrm{Cu}$ \\
\hline $\mathrm{P} 110$ & 0.28 & 0.26 & 1.68 & 0.03 & 0.013 & 0.0013 & 0.04 & 0.03 & 0.044 \\
\hline $13 \mathrm{Cr}$ & 0.03 & 0.18 & 0.44 & 12.5 & 0.02 & 0.01 & 5.82 & 2.0 & 0.51 \\
\hline
\end{tabular}

Table 2: Mechanical properties of $\mathrm{P} 110$ and $13 \mathrm{Cr}$

\begin{tabular}{|c|c|c|c|c|}
\hline Material & Tensile strength $(\mathrm{MPa})$ & Yield strength (MPa) & Elongation (\%) & Hardness (HV) \\
\hline P110 & 845 & 940 & 25 & 299 \\
\hline $13 \mathrm{Cr}$ & 855 & 970 & 20 & 323 \\
\hline
\end{tabular}

Table 3: Particle impact time every $\mathrm{mm}^{2}$

\begin{tabular}{|c|c|c|c|c|c|c|c|c|}
\hline Particle mass (g) & 50 & 100 & 200 & 400 & 800 & 1,600 & 3,200 & 6,400 \\
\hline Particle impact times & $7 \times 10^{3}$ & $1.4 \times 10^{4}$ & $2.8 \times 10^{4}$ & $5.6 \times 10^{4}$ & $1.12 \times 10^{5}$ & $2.24 \times 10^{5}$ & $4.48 \times 10^{5}$ & $8.96 \times 10^{5}$ \\
\hline
\end{tabular}


(a)

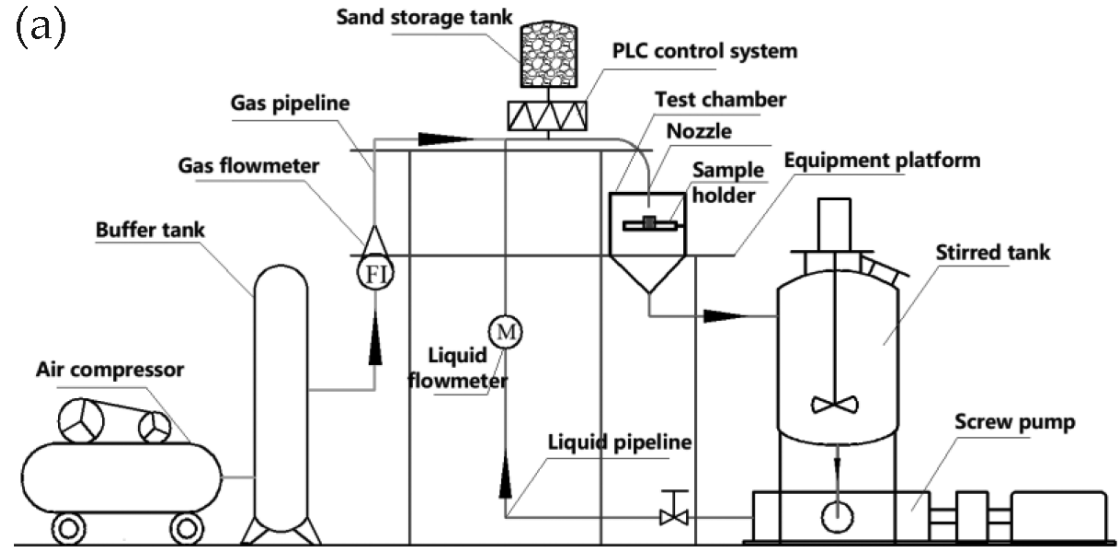

(b)

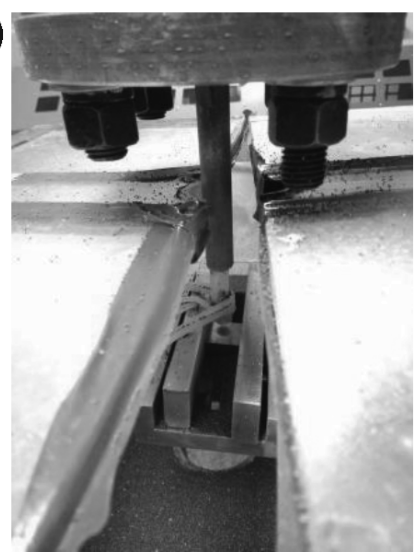

Figure 2: Jet flow experimental system: a) flow loop and b) erosion test section

experiments using a PLC screw feeder during the gas-flow process. Once the particles collided with the sample surface, they were collected in the test section and stirred tank because the sand would break after impact and affect the experimental results.

Figure $2 \mathbf{b}$ shows the erosion test section. The sample clamp can be used to adjust the angle and height of the sample in a closed space. Square P110 and 13Cr samples with dimensions of $20 \mathrm{~mm} \times 20 \mathrm{~mm} \times 5 \mathrm{~mm}$ were used in the experiment to study the particle erosion characteristics of carbon and stainless steel. Tables $\mathbf{1}$ and $\mathbf{2}$ provide the chemical composition and mechanical properties, respectively, of P110 and $13 \mathrm{Cr}$. The surfaces of the samples were ground before the experiment using 300-, 800-, and 1,200-mesh sandpapers to eliminate the impurities and obtain smooth surfaces. Ceramic particles $(\mathrm{d} p=0.6 \mathrm{~mm})$, which are weighed quantitative particles, were used in each experiment. The sample surfaces were examined through scanning electron microscopy (SEM, JSM-6390, JEOL. Co., Japan). The sizes (radius R) of the marginal impact craters in the independent impact region on the $\mathrm{P} 110$ steel and $13 \mathrm{Cr}$ stainless steel under an impact angle of $90^{\circ}$ and impact velocity of $10 \mathrm{~m} \cdot \mathrm{s}^{-1}$ were measured.

\section{RESULTS}

\subsection{Experimental results for the changes in the hardness of the target material}

The particle impact time within a unit area was calculated with the averaging method using the following formula: $N_{\text {unit }}=N_{\mathrm{c}} \div A$, where $N_{\text {unit }}$ is the number of particle impacts within a unit area. Approximately $50 \mathrm{~g}$ particles were obtained, and the number of particles was calculated in accordance with the average mass of a single particle. The particle mass in each experiment was the same as that in a previous experiment, and the numbers of impacting particles every $\mathrm{mm}^{2}$ were calculated, as shown in Table 3.

Figure 3 displays the posti-mpact Vickers hardness values on the impact surface. The hardness value of the
P110 steel changed within the range 296-303 HV when the particle impact time was less than $2.8 \times 10^{4}$. Meanwhile, the hardness values of the P110 and $13 \mathrm{Cr}$ steel increased by $63.19 \mathrm{HV}$ and $42.38 \mathrm{HV}$, respectively, when the particle impact time was $8.96 \times 10^{4}$. These results indicate that the sensitivity of the P110 steel to impact was higher than that of the $13 \mathrm{Cr}$ steel. In addition, the increment in hardness gradually decreased as the material hardness increased with impact time. Therefore, nonlinear fitting can be conducted by using the logarithmic function $y=a-b \times \lg (x+c)$ to obtain the curve of the relationship between the hardness and the particle impact times. As shown in Figure 3, the calibrated determination coefficients of both materials after fitting exceeded 0.97, which is indicative of the favorable regression of the fitted curve. These results show that the change in surface hardness under unit impact times was negligible in the initial particle impact phase (within $2 \times$ $10^{4}$ times) and peaked in the early and middle impact phases $\left(2 \times 10^{4}\right.$ to $1 \times 10^{5}$ times $)$. However, the change in surface hardness under unit impact times in the middle later phase $\left(N_{\mathrm{c}}>1 \times 10^{5}\right)$ was minor. Thus, the surface hardness reaches dynamic stability during long-term particle impacts.

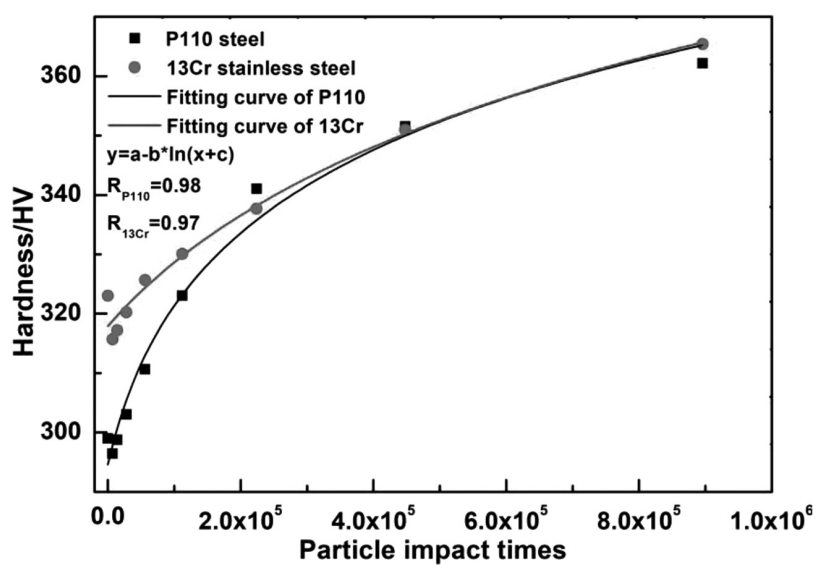

Figure 3: Changes in the surface hardness of $\mathrm{P} 110$ and $13 \mathrm{Cr}$ steel under multiple particle impacts 


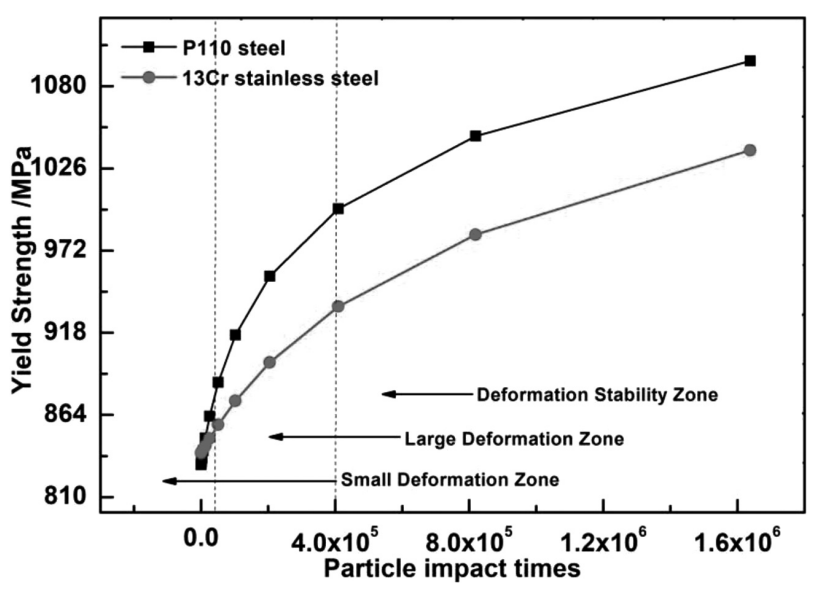

Figure 4: Relationship between yield strength and particle impact times

Figure 4 illustrates the relationship between the particle impact times and the yield strength of the wall material surface calculated using Equation (9). The yield strengths of the surfaces of both materials were less than $900 \mathrm{MPa}$ when the impact time was less than 20,000. At this time, the difference in material deformation caused by particle impact on the wall surface was small. Material deformation will increase by a large margin because of the large increment in yield strength when the impact time was 50,000-400,000. Therefore, the influence of surface-material hardening on the erosion rate of a pipe during short-term service can be neglected if the particle impact time is less than the scope of the small deformation. If the particle impact time is within the scope of a large deformation, the surface hardness and yield strength at the current time should be computed, and the surface weight eroded should then be calculated. The cumulative material losses for the pipe during long-term service within small- and large-deformation intervals should be computed first. Then, the material loss within the stable deformation interval should be calculated in accordance with the service time.

\subsection{Erosion experimental results}

A $90^{\circ}$ jet flow angle was selected for the particle erosion experiment to ensure that the material surface damage can be restricted by fatigue effect but not by the cutting effect. The discrimination of surface failure was subject to the generation of $0.1 \mathrm{mg}$ weight loss and then to the minimum particle impact time that caused fatigue damage within the unit area $\left(\mathrm{mm}^{2}\right)$. Specimen weight loss in the low flow-velocity region $\left(1-5 \mathrm{~m} \cdot \mathrm{s}^{-1}\right)$ was measured once every $100 \mathrm{~g}$ particle impact (impact times within unit area: 1,000), and a subdivision was conducted with $100(10 \mathrm{~g})$ impact times. The specimen weight loss in the medium flow-velocity region $\left(5-15 \mathrm{~m} \cdot \mathrm{s}^{-1}\right)$ was measured once every $10 \mathrm{~g}$ particle impact (impact times within unit area: 100), and a subdivision was performed with $10(1 \mathrm{~g})$ impact times. The minimum particle impact time in the high flow- velocity region $\left(>15 \mathrm{~m} \cdot \mathrm{s}^{-1}\right)$ was predicted through the logarithmic fitting equation, and the results are shown in Table 4. The exponential decline in the minimum particle impact times that caused the peeling of the two materials indicates that energy can easily accumulate under high-speed particle impact to induce material to momentarily peel off the surface.

Table 4: Critical impact times of material loss under different impact velocities

\begin{tabular}{|l|c|c|c|c|c|c|c|c|c|}
\hline & \multicolumn{3}{|c|}{$\begin{array}{c}\text { Experimental } \\
\text { measurements }\end{array}$} & \multicolumn{5}{c|}{ Fitted values } \\
\hline $\begin{array}{l}\text { Impact } \\
\text { velocities } / \mathrm{m} \cdot \mathrm{s}^{-1}\end{array}$ & 1 & 2 & 4 & 8 & 12 & 16 & 20 & 24 & 30 \\
\hline $\begin{array}{l}\text { Critical impact } \\
\text { times (13Cr) }\end{array}$ & 4900 & 2400 & 600 & 210 & 60 & 32 & 13 & 5 & 1 \\
\hline $\begin{array}{l}\text { Critical impact } \\
\text { times (P110) }\end{array}$ & 3800 & 1700 & 200 & 80 & 30 & 14 & 3 & 1 & - \\
\hline
\end{tabular}

Experimental results show that the minimum particle time that caused the material loss of $13 \mathrm{Cr}$ steel under the impact velocity of $30 \mathrm{~m} \cdot \mathrm{s}^{-1}$ was approximately 1 . This finding indicates that particle impact can generate material loss only once when the flow velocity exceeded $30 \mathrm{~m} \cdot \mathrm{s}^{-1}$. The corresponding impact velocity was close to $24 \mathrm{~m} \cdot \mathrm{s}^{-1}$ when the P110 impact time was 1 . This result indicates that the threshold flow velocity that generated a single impact failure in P110 steel was low. As shown in Figure 5 and Table 5, the empirical coefficient $D$ under different impact velocities was calculated through the experimental measurement of a total indentation depth $h$ ( $h=4.7 \times 10^{-6} \mathrm{~m}$ corresponds to $0.1 \mathrm{mg}$ ), an extrusion depth $h_{S}$ of a single particle impact, and minimum particle impact times $N(D e / 2 e=N)$ causing material loss in accordance with Equation (4). The results are shown in Figure 5. The indentation depths (thinning quantity) of $13 \mathrm{Cr}$ and $\mathrm{P} 110$ steel under long-term service can be expressed as follows:

13Cr steel: $h=\left(3.7 \times 10^{-3}+0.02 \cdot e^{v / 6.7}\right) \cdot h_{\mathrm{S}} N_{\mathrm{c}}$

P110 steel: $h=\left(0.19+3.9 \times 10^{-4} \times e^{v / 2.4}\right) \cdot h_{\mathrm{S}} N_{\mathrm{c}}$

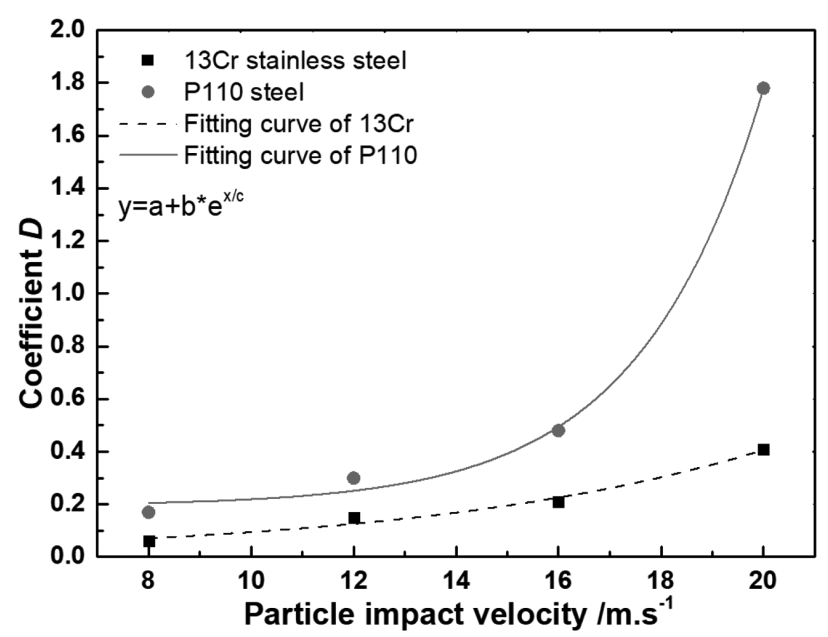

Figure 5: Coefficient $D$ versus particle impact velocities 
where $N_{\mathrm{c}}=3 r_{1}{ }^{2} \cdot u^{\mathrm{a}} \cdot Q_{\mathrm{v}} / 4 r_{\mathrm{p}}{ }^{3}$, and vertical impact velocity $v_{y}$ is adopted for the particle velocity. Therefore, the uniform thinning quantity of the pipe wall can be solved through Equation (12) or (13) when an actual two-phase pipe flow was considered as the study object. However, the precondition for calculation is that the particlecarrying capacity of the continuous phases is strong. Specifically, the interphase slipping velocity is small, and the particle velocity is identical to the continuous phase velocity by default. However, the influence of interphase force and turbulent acceleration on particle impact angle causes a continuous change in the vertical impact velocity $v_{y}$ when particles impact the wall surface in the actual processes.

Table 5: Variation in coefficient $D$ with particle impact velocities

\begin{tabular}{|c|c|c|c|c|}
\hline \multirow{2}{*}{$\begin{array}{c}\text { Coefficient } \\
D\end{array}$} & \multicolumn{4}{|c|}{ Particle impact velocity $/ \mathrm{m} \cdot \mathrm{s}^{-1}$} \\
\cline { 2 - 5 } & 8 & 12 & 16 & 20 \\
\hline $13 \mathrm{Cr}$ & $590,485.34$ & $32,087.08$ & $6,840.11$ & 902.70 \\
\hline $\mathrm{P} 110$ & $85,694.02$ & $8,021.77$ & $1,309.24$ & 48.07 \\
\hline
\end{tabular}

\section{CONCLUSIONS}

The single-particle impact erosion model combined with the erosion-forecasting model for multi-particle impact on metal wall surfaces was established in this work on the basis of the low-cycle fatigue theory. A jet flow-type erosion experiment was performed to identify the trends shown by changes in the surface-hardness values of P110 steel and $13 \mathrm{Cr}$ with particle impact times. Moreover, key empirical coefficients were acquired. Experimental results showed that the material hardness logarithmically increased when the particles impacted the two metal surfaces. An ideal corresponding material erosion rate was obtained under long-term particle impact when the surface hardness region was stable. In addition, the local yield strength of the material surface will increase because of the hardening effect exerted by the particle impact. Consequently, the particle indentation depth reduced. Given that particle impact energy was absorbed during plastic material deformation, material loss was the product of multi-particle impacts under most circumstances. The minimum particle-impact time that caused material peeling exponentially declined with the impact velocity. This finding indicates that material loss was equivalent to the linear superposition of single losses when the impact velocity reached a certain value, and the influence of material fatigue can be neglected.

\section{Acknowledgment}

This research was funded by Basic Research Program of Natural Science of Shaanxi Province (No. 2019JQ-809), and supported by National Natural Science Foundation of China under grant number 51674199.

\section{Appendix A}

\begin{tabular}{|c|l|}
\hline \multicolumn{2}{|c|}{ Nomenclature } \\
\hline$C_{\mathrm{E}}$ & erosion rate, $\mathrm{mm} \cdot \mathrm{s}^{-1}$ \\
\hline$E^{*}$ & equivalent elastic modulus, $\mathrm{Pa}$ \\
\hline$F_{x}$ & tangential contact force, $\mathrm{N}$ \\
\hline$F_{y}$ & normal contact force, $\mathrm{N}$ \\
\hline$h$ & total indentation depth, $\mathrm{m}$ \\
\hline$k_{\mathrm{s}}$ & intensity factor, $\mathrm{Pa}$ \\
\hline$L$ & scratch length, $\mathrm{m}$ \\
\hline$m_{\mathrm{p}}$ & particle mass, $\mathrm{kg}$ \\
\hline$N$ & $\begin{array}{l}\text { critical particle impact time corresponding to } \\
\text { material loss }\end{array}$ \\
\hline$N_{\mathrm{c}}$ & actual particle impact time in a unit area \\
\hline$r_{\mathrm{p}}$ & particle radius, $\mathrm{m}$ \\
\hline$r$ & tube radius, $\mathrm{m}$ \\
\hline$u$ & pipe flow velocity, $\mathrm{m} \cdot \mathrm{s}{ }^{-1}$ \\
\hline$v_{x}$ & tangential velocity of the particle, $\mathrm{m} \cdot \mathrm{s}^{-1}$ \\
\hline$v_{y}$ & normal velocity of the particle, $\mathrm{m} \cdot \mathrm{s}^{-1}$ \\
\hline$s$ & stress, Pa \\
\hline$s_{y}$ & vertical material yield limit, Pa \\
\hline$D e$ & plastic strain scope \\
\hline$\mu$ & coefficient of friction, dimensionless \\
\hline$\lambda_{x}$ & $\begin{array}{l}\text { velocity attenuation coefficient in tangential } \\
\text { direction, dimensionless }\end{array}$ \\
\hline$\lambda_{y}$ & $\begin{array}{l}\text { velocity attenuation coefficient in normal direction, } \\
\text { dimensionless }\end{array}$ \\
\hline
\end{tabular}

\section{REFERENCES}

${ }^{1}$ J. G. A. Bitter, Study of erosion phenomenon-I, Wear, 6 (1963), 169-176, doi:10.1016/0043-1648(63)90003-6

${ }^{2}$ G. P. Tilly, Two stage mechanism of ductile erosion, Wear, 23 (1973), 87-96, doi:10.1016/0043-1648(73)90044-6

${ }^{3}$ I. M. Hutchings, Particle erosion of ductile metals: A mechanism of material removal, Wear, 27 (1974), 121-128, doi:10.1016/00431648(74)90091-X

${ }^{4}$ J. H. Neilson, A. Gilchrist, Erosion by a stream of solid particles, Wear, 11 (1968), 111-122, doi:10.1016/0043-1648(68)90591-7

${ }^{5}$ G. L. Sheldon, Similarities and differences in the erosion behavior of materials, J. Basic Eng., 92 (1970), 619-626, doi:10.1115/1.3425086

${ }^{6}$ I. Finnie, Erosion of surfaces by solid particles, Wear, 3 (1960), 87-103, doi:10.1016/0043-1648(60)90055-7

${ }^{7}$ G. P. Tilly, Two Stage Mechanism of ductile erosion, Wear, 23 (1973), 87-96, doi:10.1016/0043-1648(73)90044-6

${ }^{8}$ Y. J. Guo, Y. Y. Wang, Y. X. Pang, Research on erosion fatigue of carbon steel surface, J. Vib. Shock., 24 (2005), 44-49

${ }^{9}$ I. M. Hutchings, A model for the erosion of metals by spherical particles at normal incidence, Wear, 70 (1981), 269-281, doi:10.1016/0043-1648(81)90347-1

${ }^{10}$ C. K. Huang, S. Chiovelli, A comprehensive phenomenological model for erosion of materials in jet flow, Powder Technol., 187 (2008), 237-279, doi:10.1016/j.powtec.2008.03.003

${ }^{11}$ J. R. Cheng, N. S. Zhang, L. Wei, H. X. Mi, Y. H. Dou, A new phenomenological model for single particle erosion of plastic materials, Materials, 12 (2018), 135-154, doi:10.3390/ma12010135

${ }^{12}$ Z. Z. Hu, S. Z. Cao, Relation between strain-hardening exponent and strength, J. Xian Jiaotong Univ. 27 (1993), 72-76

${ }^{13}$ S. H. Shi, G. Y. Fu, J. J. Shi, Strain-hardening and softening of laser coating component under the cyclic repeated impact, Laser. Infrared. 35 (2005), 554-556

${ }^{14}$ E. J. Pavlina, C. J. V. Tyne, Correlation of yield strength and tensile strength with hardness for steels, J. Mater. Eng. Perform., 17 (2008), 888-893, doi:10.1007/s11665-008-9225-5 